\title{
Productivity of Eight Leafy Vegetable Crops Grown Under Shade in Hawaii
}

\author{
Xenia Y. Wolff ${ }^{1}$ and Robert R. Coltman ${ }^{2}$ \\ Department of Horticulture, University of Hawaii, Honolulu, HI 96822 \\ Additional index words. lettuce, Lactuca sativa, Chinese cabbage, Brassica rapa (Pekinensis Group), green mustard \\ cabbage, Brassica juncea, head cabbage, Brassica oleracea (Capitata Group), green bunching onion, Allium fistulosum
}

\begin{abstract}
Green Mignonette', 'Salinas', 'Parris Island Cos', and 'Amaral 400' lettuce (Lactuca sativa L.); 'WR-55 Days' Chinese cabbage (Brassica rapa L. Pekinensis Group); Waianae Strain' green mustard cabbage [Brassica juncea (L.) Czerniak]; 'Tastie Hybrid' head cabbage (Brassica oleracea L. Capitata Group); and an unnamed local selection of green bunching onions (Allium fistulosum L.) were field-grown during Fall 1987 and Spring 1988 at Waimanalo, Oahu, Hawaii, in full-sun and with four artificially produced levels of shade $(30 \%, 47 \%, 63 \%$, and $73 \%)$. Yields of cos lettuce, green mustard cabbage, and green bunching onions were irresponsive to shade or negatively affected by shade in both seasons. Yield responses of the other crops to shade varied seasonally. Optimum shading of $30 \%$ to $47 \%$ increased 'Green Mignonette', 'Salinas', and 'Amaral 400' lettuce yields by $36 \%$ and head cabbage and Chinese cabbage yields by $23 \%$ and $21 \%$, respectively, compared to full-sun plots in one or both seasons. Leaf areas similar to unshaded controls were maintained as shade intensity increased, while leaf dry weight decreased in all crops except 'Salinas' and 'Parris Island Cos' lettuce. Maximum rates of net photosynthesis (Pn) were attained at $1500 \mathbf{u m o l}^{-1} \cdot \mathrm{m}^{-2}$, which was about two-thirds of full sunlight.
\end{abstract}

Production of temperate leafy green vegetables, such as lettuce and members of the genus Brassica, is most often carried out in cool environments with low solar radiation (Glenn, 1984). In tropical and subtropical regions, this apparent requirement limits production to highland areas and to the lowland tropics during the cool season. Photosynthetic photon flux (PPF) is considerably higher in tropical than in temperate regions, resulting in higher temperatures and higher evapotranspirative demands (Glenn, 1984; Sale, 1975). Poor head formation, leaf twisting, early bolting, and reduced yields have occurred when temperate leafy vegetables are grown under hot, high-sunlight conditions (Nothmann, 1977; Sajjapongse and Roan, 1983). Water stress caused by high evapotranspirative demand, and high air and soil temperatures, appear to be the main causes of poor crop productivity of leafy crops in low-latitude regions (Nothmann, 1977; Yamaguchi et al., 1975).

Yields of semihead lettuce previously were found to be enhanced with artificial shading during the fall in Hawaii (Wolff and Coltman, 1989). The present study was undertaken to confirm these results and to evaluate the effects of shade on photosynthesis, leaf morphology, and yield of a wider range of the leafy vegetable crops typically grown year-round in Hawaii.

\section{Materials and Methods}

Field preparation. A 0.17-ha field at Waimanalo Agricultural Research Station, Oahu, Hawaii, was prepared for a Fall 1987 planting using local recommendations on soil preparation and fertilization for lettuce, Chinese cabbage, mustard cabbage, head cabbage, and green bunching onions (Hartmann et al., 1978a, 1978b; Takeda and Sakuoka, 1979). The Typic Haplustoll soil was amended with $84 \mathrm{~kg} \mathrm{~N}, 109 \mathrm{~kg} \mathrm{P}$, and $67 \mathrm{~kg} \mathrm{~K}$ per ha and fumigated with $200 \mathrm{~kg} \cdot \mathrm{ha}^{-1}$ of methyl bromide (98\% a.i.) to

Received for publication 9 Jan. 1989. Journal Series no. 3347 of the Hawaii Institute of Tropical Agriculture and Human Resources. X.Y.W. was supported by a grant from the Resource Systems Institute, East-West Center. We thank American Takii, Inc., for donating the 'WR-55 Days' Chinese cabbage seeds and Quali-Sel Seed and Royal Sluis, Inc., for donating the 'Amaral 400' and 'Salinas' lettuce seeds used in these studies.

'Former graduate student. Present address: USDAARS, Southern Univ. Center for Small Farm Research, P.O. Box 11170, Baton Rouge, LA 70813.

${ }^{2}$ Associate Professor. control weeds. For Spring 1988, the field was reworked and refertilized as for Fall 1987.

Experimental design. Shadecloth canopies were erected over each of 25 plots. Supports were $10 \mathrm{~cm} \mathrm{x} 10 \mathrm{~cm} \times 3-\mathrm{m}$ wooden beams set at the corners of $7.6 \times 9.1-\mathrm{m}$ plots and anchored 1 $\mathrm{m}$ deep in the soil in a grid-shaped pattern. Galvanized $0.6-\mathrm{cm}$ diameter wire rope was strung between the beams $1.8 \mathrm{~m}$ above the ground, and grometted panels of commercial black plastic shadecloth were suspended from the wire rope. Five replicates of each of five shade levels [0\% (open sun), $30 \%, 47 \%, 63 \%$, and $73 \%$ ] were completely randomized in the field. Minimum and maximum air temperatures were monitored daily using minimum-maximum thermometers, and soil water tension was monitored daily with tensiometers placed $18 \mathrm{~cm}$ deep. Temperatures $10 \mathrm{~cm}$ below the soil surface in the $0 \%, 47 \%$, and $73 \%$ shade plots were monitored daily for 2 weeks during Spring 1988, using thermistors and an Omnidata EL-824 datalogger (Omnidata Intl., Logan, Utah). Evaporimeters (Ekern, 1983) were used to monitor daily evaporation with $0 \%$ and $73 \%$ shade. Precipitation and total solar irradiance (SI) in the open sun were monitored daily using a LI-COR LI-1200 datalogger equipped with a tipping-bucket rain gauge and an LI-200SA pyranometer (LI-COR, Lincoln, Neb.).

Total SI (MJ/m $\mathrm{m}^{2}$ per crop) in the open sun was converted to total photosynthetically active radiation (PAR, $\mathrm{mol} / \mathrm{m}^{2}$ per crop) using the conversion determined by Meek et al. (1984). Measurements made with a LI-COR LI-191SA Line Quantum Sensor verified the percent PAR transmittance of the shadecloth canopies as commercially specified. Nonattenuation of longand short-wave radiation was assumed. Total PAR received by each crop was used instead of percent shade in discussing plant responses because total PAR received varied among crop types (due to differing lengths of time in the field) and seasons, and percent shade as a predictor variable would not reflect these differences.

Cultural conditions. Six 4-m-long rows each of 'Green Mignonette' (a semihead type known locally as "Manoa"), 'Salinas', 'Amaral 400', and 'Parris Island Cos' lettuce; 'WR-55 Days' Chinese cabbage; 'Waianae Strain' green mustard cabbage; 'Tastie Hybrid' head cabbage; and an unnamed local selection of green bunching onions were grown simultaneously in 
Table 1. Planting and harvest dates, days to harvest, and cultural practices for four cultivars of lettuce, 'WR-55 Days' Chinese cabbage, 'Waianae Strain' green mustard cabbage, 'Tastie Hybrid' head cabbage, and a local unnamed selection of green bunching onions grown during Fall 1987 and Spring 1988.

\begin{tabular}{|c|c|c|c|c|c|c|c|c|c|}
\hline \multirow[b]{2}{*}{ Crop } & \multicolumn{2}{|c|}{ Planting date } & \multicolumn{2}{|c|}{ Harvest date } & \multicolumn{2}{|c|}{ Days to harvest } & \multirow{2}{*}{$\begin{array}{c}\text { No. } \\
\text { plants } \\
\text { per row }\end{array}$} & \multirow{2}{*}{$\begin{array}{l}\text { Spacing } \\
\text { between } \\
\text { rows }(\mathrm{cm})\end{array}$} & \multirow{2}{*}{$\begin{array}{c}\text { Spacing } \\
\text { between } \\
\text { plants }(\mathrm{cm})\end{array}$} \\
\hline & $\begin{array}{c}\text { Fall } \\
1987\end{array}$ & $\begin{array}{c}\text { Spring } \\
1988\end{array}$ & $\begin{array}{c}\text { Fall } \\
1987\end{array}$ & $\begin{array}{c}\text { Spring } \\
1988\end{array}$ & $\begin{array}{c}\text { Fall } \\
1987\end{array}$ & $\begin{array}{c}\text { Spring } \\
1988\end{array}$ & & & \\
\hline \multicolumn{10}{|l|}{ Lettuce } \\
\hline \multicolumn{10}{|l|}{ 'Green } \\
\hline Mignonette' & 18 Aug. $z$ & $28 \mathrm{Apr}$ & -.- & 9 June & $\cdots$ & 42 & 15 & 30 & 24 \\
\hline 'Salinas' & 8 Sept.y & 28 Apr. & 30 Oct. & 14 June & 52 & 47 & 15 & 30 & 24 \\
\hline 'Parris Island Cos' & 18 Aug. & 28 Apr. & 6 Oct. & 16 June & 49 & 49 & 15 & 30 & 24 \\
\hline 'Amaral 400' & 18 Aug. & $28 \mathrm{Apr}$. & 13 Oct. & 14 June & 56 & 47 & 15 & 30 & 24 \\
\hline \multicolumn{10}{|l|}{ Cabbage } \\
\hline Chinese & 18 Aug. & 28 Apr. & 13 Oct. & 7 June & 56 & 40 & 12 & 30 & 30 \\
\hline Mustard & 18 Aug. & $28 \mathrm{Apr}$. & 6 Oct. & 7 June & 49 & 40 & 12 & 30 & 30 \\
\hline Head & 18 Aug. & 3 May & 13 Oct. & 16 June & 56 & 44 & 12 & 30 & 30 \\
\hline Bunching onion & 19 Aug. & 3 May & 13 Oct. & 14 June & 55 & 42 & $15^{x}$ & 30 & 24 \\
\hline
\end{tabular}

${ }^{\text {zReplanted } 15 \text { Sept. }}$

y18 Aug. planting did not germinate.

xPlanted two stalks together.
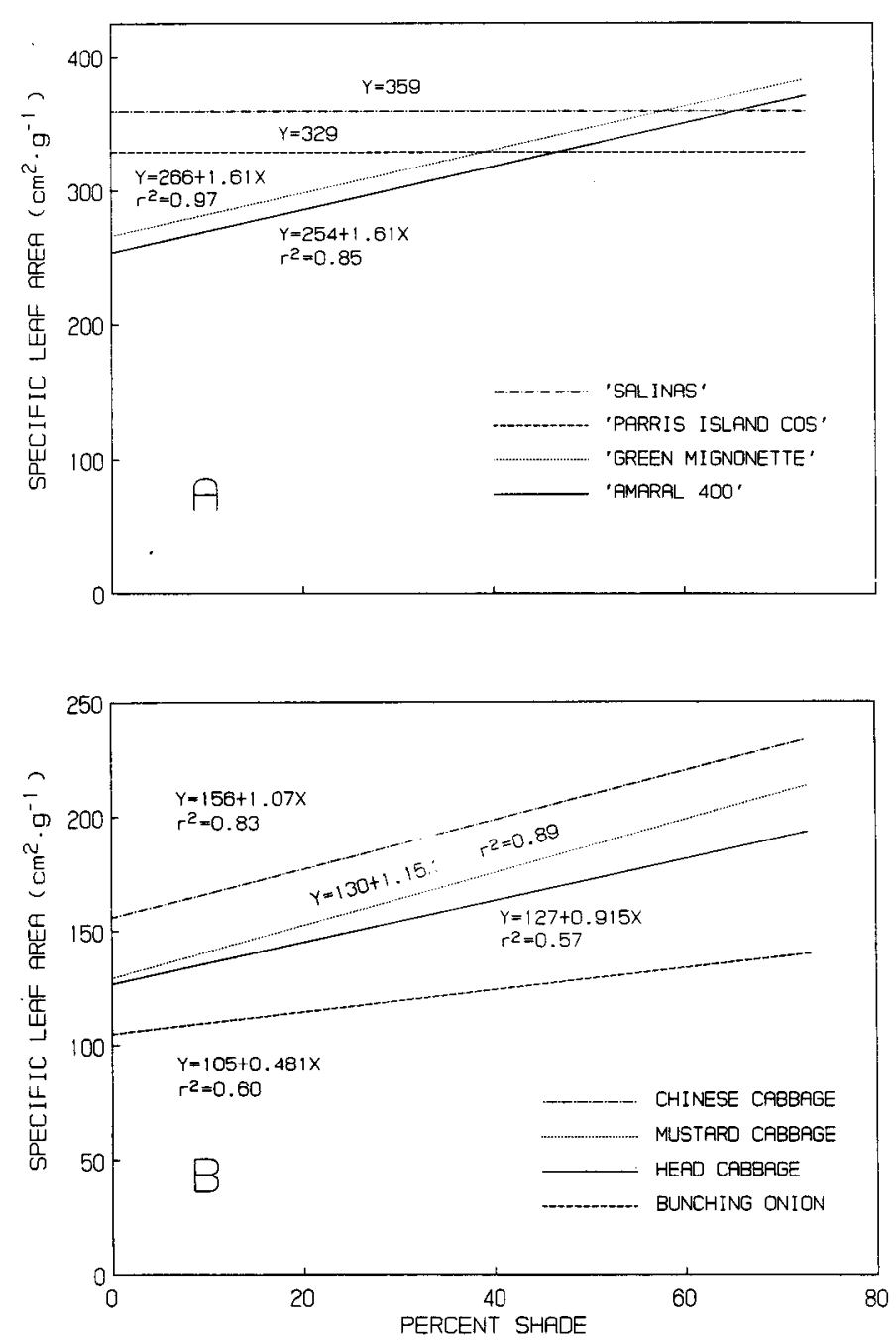

Fig. 1. Specific leaf area of 'Green Mignonette', 'Salinas', 'Parris Island Cos', and 'Amaral 400' lettuce (A) and 'WR-55 Days' Chinese cabbage, 'Waianae Strain' green mustard cabbage, 'Tastie Hybrid' head cabbage, and an unnamed local selection of green bunching onions (B) at harvest maturity averaged over both experiments as a function of percent shade. each plot. Crop subplots were randomized within each shade level plot to minimize border effects. Data were collected only from the four internal rows in crop subplots.

The head cabbage was seeded 22 June 1987 (Fall 1987) and 9 Apr. 1988 (Spring 1988) into transplant flats with 5-cm-diameter, $100-\mathrm{cm}^{3}$ cells that contained a mixture of 1 peat : 1 vermiculite (v/v) amended with $271 \mathrm{~g}$ dolomite and $139 \mathrm{~g}$ gypsum per $\mathrm{m}^{3}$. Micronutrients and slow-release nutrients were incorporated as $33 \mathrm{~g}$ Micromax and $1109 \mathrm{~g}$ Osmocote (19N-2.6P10K) (Sierra Chemical, Milpitas, Calif.) per $\mathrm{m}^{3}$, respectively. Dates of transplanting of the head cabbage seedlings and the green bunching onion sets, and of direct-seeding of the other six crops, along with dates of harvest, number of plants per row, and between- and within-row spacing are presented in Table 1. Experimental plot size for all crops was $1.2 \times 4.0 \mathrm{~m}$. Final spacing of the direct-seeded crops was achieved by thinning 3 to 4 weeks after planting. In Fall 1987, 'Salinas' and 'Green Mignonette' lettuce seed germinated very poorly, possibly due to thermodormancy, and plots for these crops were reseeded 8 and 15 Sept. 1987, respectively. The second planting of 'Salinas' was successful, but again 'Green Mignonette' did not germinate. All plants were fertilized by banding $84 \mathrm{~kg} \mathrm{~N}$, $109 \mathrm{~kg} \mathrm{P}$, and $67 \mathrm{~kg} \mathrm{~K}$ per ha 4 weeks after planting. The plots were drip-irrigated up to three times per week (based on the appearance of the soil surface) at an average rate of $5 \mathrm{~mm} \cdot \mathrm{day}^{-1}$ only to supplement natural rainfall. All plots were irrigated equally regardless of shade level. Weeding was done by hand.

Leaf area and dry weight measurements. Characteristics of leaf morphology as influenced by shading were determined on three young, fully expanded leaves per subplot collected for leaf area and leaf dry weight measurements at harvest maturity. Leaf area was measured using a LI-COR LI-31OO Area Meter. Leaves were dried for at least $48 \mathrm{hr}$ at $65 \mathrm{C}$ before weighing.

Elemental analysis of plant tissue. Three young, fully expanded leaves per subplot were collected at harvest maturity in Fall 1987 only. These samples were bulked according to crop type and shade treatment, and analyzed for N (Coltman, 1987) and P, K, Ca, Mg, and B (Wallace and Barrett, 1981).

Photosynthetic data. Photosynthesis data were collected for all crops under all shade levels to investigate the influence of shading on net photosynthesis (Pn). Rates of Pn in two young, 

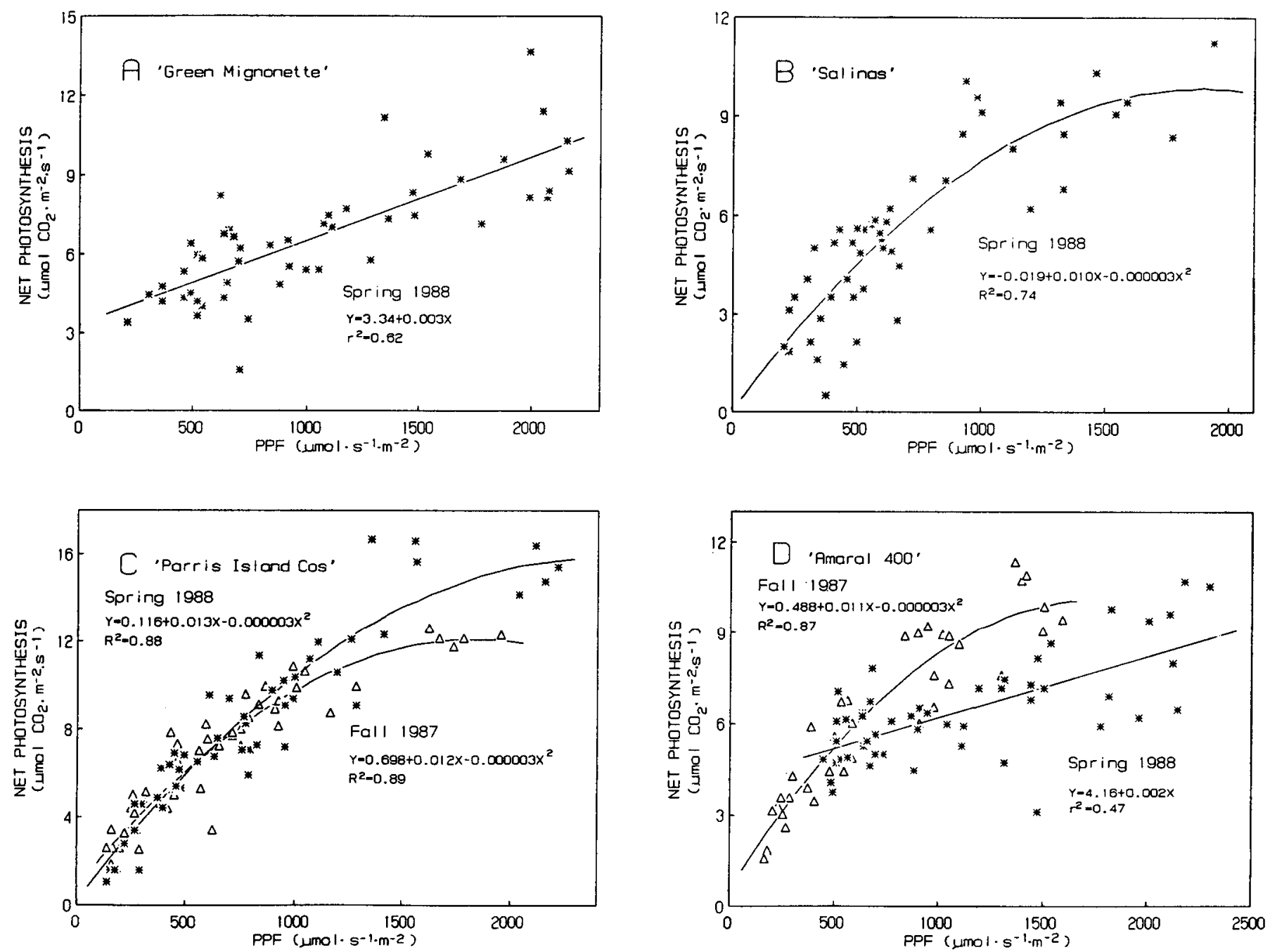

Fig. 2. Photosynthetic rates of four lettuce cultivars at harvest maturity during Fall 1987 and Spring 1988 as a function of photosynthetic photon flux (PPF).

fully expanded leaves were determined in situ in all subplots using a LI-COR LI-6000 Portable Photosynthesis System equipped with a quantum sensor (L1190-SA) to measure photosynthetic photon flux (PPF, $\left.\mu \mathrm{mol} \cdot \mathrm{s}^{-1} \cdot \mathrm{m}^{-2}\right)$. The LI-6000 leaf chamber was attached to the leaf so as to not change the orientation of the leaf toward the sun. Photosynthesis data for all crops were taken at harvest maturity during both experiments. Because of technical complications, data were taken during the spring planting only for 'Green Mignonette' and 'Salinas' lettuce and green bunching onions. Ten readings $6 \mathrm{sec}$ apart per measurement were taken between 1000 and 1400 HR during bright sky conditions. A continuous range of PPF and Pn rates resulted from varying cloud cover while measurements were made among the plots.

Harvest procedures. Total fresh head weights or fresh bunch weights (green bunching onions) were determined from a single harvest when each crop reached harvest maturity. The criterion for harvest maturity of the heading crops was the development of compact heads ("heading up"), and, for the green bunching onions, the attainment of marketable bunch size. Total above-ground biomass was weighed to avoid subjectivity in trimming among treatments, Therefore, comparisons of experimental yields with commercial yields were deemed unsuitable.
Best-fit curves for leaf area, leaf dry weight, photosynthetic rate, and harvest yield vs. shade, PPF, or estimated PAR were calculated using polynomial models. Seasonal comparisons were made by testing light $\times$ season interactions. Only coefficients significant at $P=0.05$ were retained in the models.

\section{Results and Discussion}

Leaf morphology. Specific leaf area (leaf area/leaf dry weight = SLA) of 'Green Mignonette' and 'Amaral 400' lettuce, Chinese cabbage, green mustard cabbage, head cabbage, and green bunching onions increased as percent shade increased due to reduction of leaf dry weights by shading, while leaf areas were maintained (Fig. $1 \mathrm{~A}$ and B). This result indicates some limited genetic ability for morphological adaptation to shade in these crops. The production of broad leaves is a common characteristic of plants growing in natural shady environments, presumably because it increases the light interception possible per unit of structural biomass (Boardman, 1977). The relationship of leaf dry weight to leaf area was similar in both seasons with these six crops. 'Salinas' and 'Parris Island Cos' lettuce SLA were unaffected by shade in either Fall 1987 or Spring 1988 because leaf area and dry weight were not affected by shade level.

Elemental analysis of plant tissue. Shading had no effect on 

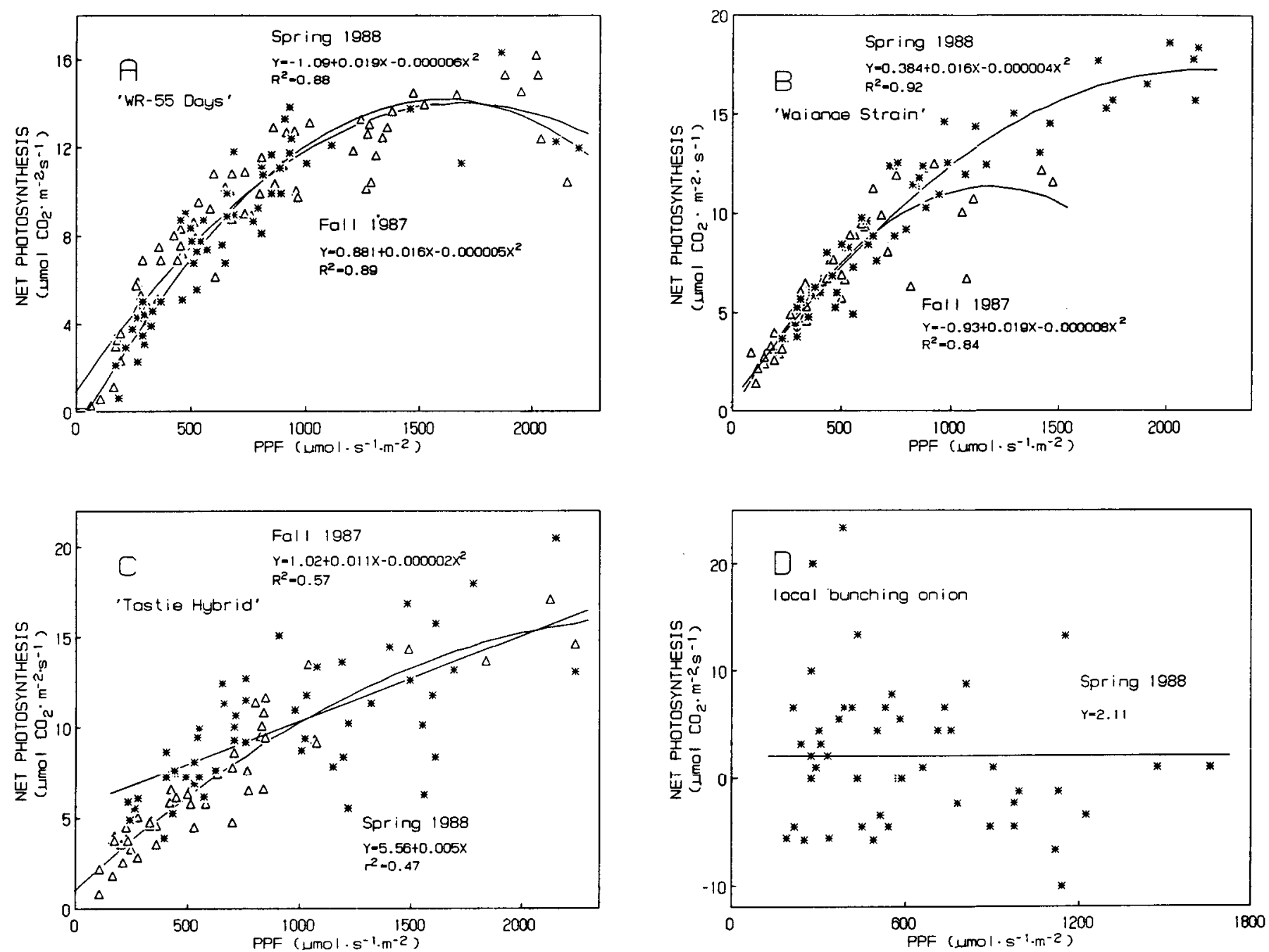

Fig. 3. Photosynthetic rate of 'WR-55 Days' Chinese cabbage (A), 'Waianae Strain' green mustard cabbage (B), 'Tastie Hybrid' head cabbage (C), and an unnamed local selection of green bunching onions (D) at harvest maturity during Fall 1987 and Spring 1988 as a function of photosynthetic photon flux (PPF).

tissue nutrient contents, including percent $\mathrm{N}$ (data not shown). Tissue contents of the four lettuce cultivars indicated adequate mineral nutrition based on published values (Lorenz and Tyler, 1983). Nutritional levels were assumed to be adequate for the other' leafy crops.

Photosynthetic rates. Net carbon assimilation rates of 'Green Mignonette' lettuce increased linearly up to the highest PPF observed with full sunlight $\approx\left(2200 \mu \mathrm{mol} \cdot \mathrm{s}^{-1} \cdot \mathrm{m}^{-2}\right)$; the maximum Pn rate was $\approx 10 \mu$ mol $\mathrm{CO}_{2} / \mathrm{m}^{2}$ per sec (Fig. $\left.2 \mathrm{~A}\right)$. We previously found $\mathrm{Pn}$ rates of this cultivar to plateau at about half of full sunlight (Wolff and Coltman, 1989). The reason for this discrepancy is unknown. Maximum Pn rates of 9 to 14 $\mu \mathrm{mol} \mathrm{CO}_{2} / \mathrm{m}^{2}$ per sec of 'Salinas', 'Parris Island Cos', and 'Amaral 400' lettuce; Chinese cabbage; green mustard cabbage; and head cabbage were reached between PPFs of 1500 and 1750 $\mu \mathrm{mol} \cdot \mathrm{s}^{-1} \cdot \mathrm{m}^{-2}$ (two-thirds to three-fourths of full sunlight) (Figs. 2 B-D and 3 A-C). Light saturation of entire crops of head lettuce at average maximum light intensities of 1500 $\mu \mathrm{mol} \cdot \mathrm{s}^{-1} \cdot \mathrm{m}^{-2}$, and of entire crops of head cabbage at 1600 $\mu \mathrm{mol} \cdot \mathrm{s}^{-1} \cdot \mathrm{m}^{-2}$, with decreased Pn rates at higher light intensities, were reported previously (Mattei et al., 1973; Sale, 1975). Net photosynthesis rates of green bunching onions did not re- spond to increasing light levels for the light intensities tested (Fig. 3D). The midday closure of onion stomata (Heath, 1969) probably accounts for this unresponsiveness of onion Pn to shading.

Maximum rates of $\mathrm{Pn}$ appeared to be higher and occur at higher PPF levels for 'Parris Island Cos' and 'Amaral' lettuce and mustard cabbage in Spring 1988 than in Fall 1987. Interestingly, lower rather than higher yields of these crops were associated with the higher maximum Pn rates in the spring compared to the fall (Figs. $4 \mathrm{C}$ and D and 5A). Most crops matured faster in Spring 1988 than in Fall 1987 (Table 1). High growth rates associated with high $\mathrm{Pn}$ rates may not necessarily be desirable for maximizing yields.

Yields. Total fresh head yields of 'Green Mignonette' lettuce grown during Spring 1988 were $53 \%$ greater when total PAR was reduced by $47 \%$ relative to plots grown in the full-sun (Fig. 4A). The germination failure of 'Green Mignonette' during Fall 1987 was probably due to poor seed quality and/or seed thermodormancy. Previous plantings of 'Green Mignonette' in the same field with a different seed lot had resulted in high-quality crops (Wolff and Coltman, 1989).

In Fall 1987, 'Salinas' and 'Amaral 400' lettuce yields de- 

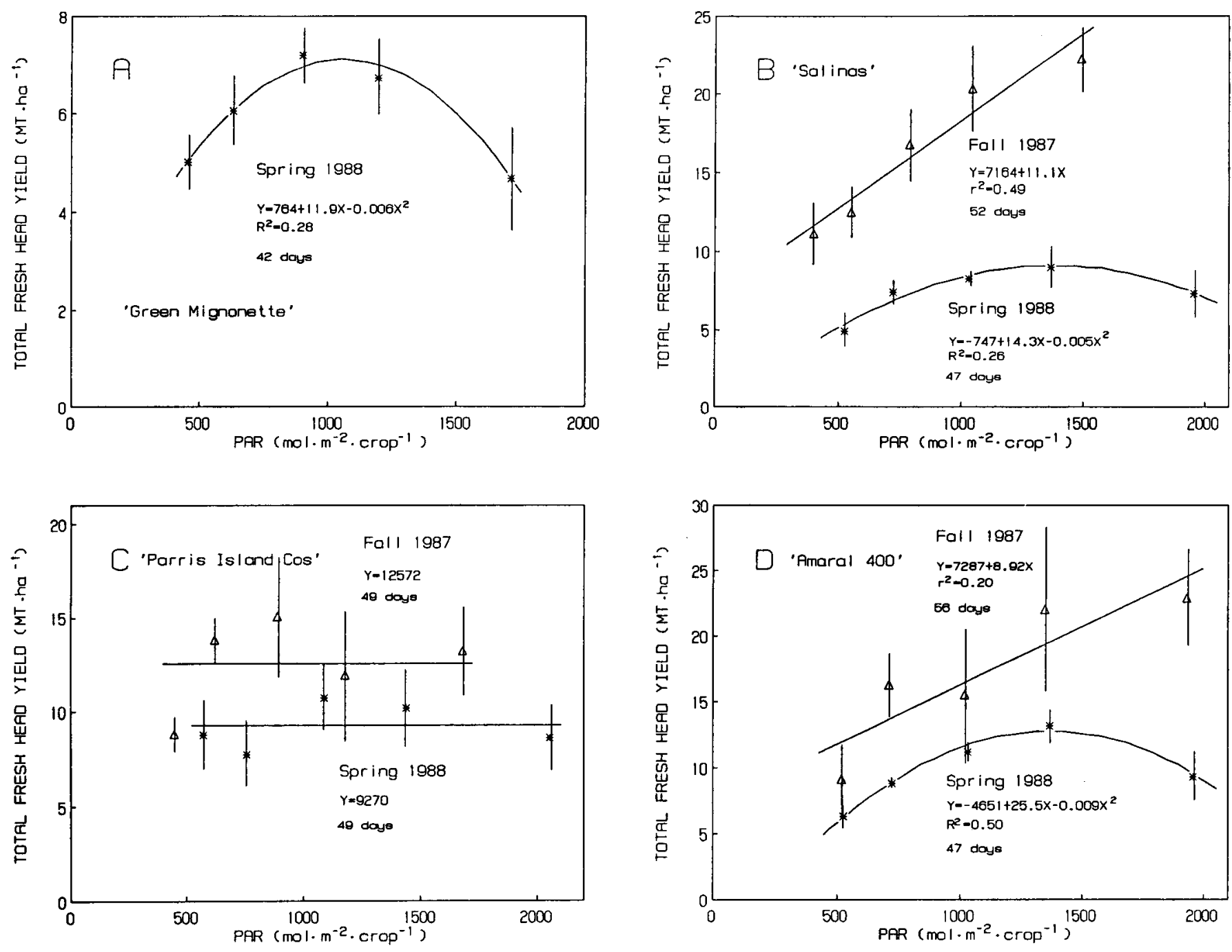

Fig. 4. Total fresh head weight yields of four lettuce cultivars grown during Fall 1987 and Spring 1988 as a function of accumulated photosynthetically active radiation (PAR) per crop. Days indicated is length of crop cycle. Vertical bars represent the SE.

creased linearly with shading, while, in Spring 1988, yields of 'Salinas' and 'Amaral 400' lettuce were increased by $22 \%$ and $40 \%$, respectively, in $30 \%$ shade (Fig. $4 \mathrm{~B}$ and D). 'Parris Island Cos' lettuce yields did not respond to shading in either season (Fig. 4C). Individual head weights of these three lettuce cultivars were lower than commercially acceptable weights $(\geq 0.68$ $\mathrm{kg}$ ), regardless of shade level, probably due to supraoptimal temperatures. These cultivars are commercially produced in Hawaii at cooler, higher elevations than that of the experimental site.

For all crops studied, length of time to harvest maturity depended on crop type and season, not shade level, with harvest maturity occurring simultaneously under all shade levels for a particular crop. Similarly, differences in amount of accumulated PAR received among crop types was due to both season and length of time in the field for each crop.

Yields of 'WR-55 Days' Chinese cabbage were increased by moderate shade in Fall 1987, a 30\% reduction in total PAR received in the open sun, resulting in a $21 \%$ yield increase (Fig. 5A). In Spring 1988, yields decreased linearly with increasing shade level. The interaction between season and PAR levels was not significant at $P=0.05$.

Fresh head yield of 'Waianae Strain' green mustard cabbage decreased linearly with increasing shade in both Fall 1987 and Spring 1988 (Fig. 5B). Overall yields were considerably higher in the fall. Seasonal interactions again were not significant.

Head cabbage yields were higher in Spring 1988 than in Fall 1987, although seasonal differences were not pronounced between fall and spring crops grown in full sun (Fig. 5C). In Spring 1988, shading up to $47 \%$ increased yields by $23 \%$ compared to the no-shade plots, while, in the fall, yields were reduced significantly by any amount of shading.

Green bunching onion yields were reduced sharply by shading in Fall 1987, but Spring 1988 yields did not respond to shading (Fig. 5D).

During Fall 1987, shading had no effect on soil water tension (Table 2), probably due to the abundant rainfall experienced in Fall 1987 compared to Spring 1988 (Fig. 6) and the consequent lack of supplemental irrigation. Soil water tension was reduced significantly by shading during Spring 1988 (Table 2). Leafy vegetables subjected to water stress exhibit slow growth and tipburn (Hartmann et al., 1978a, 1978b; Takeda and Sakuoka, 1979). Some tipburn was observed in Spring 1988 on all crops grown in the full-sun plots, except green bunching onion, but no quantitative data were taken. The reduction of soil water tension with shading during Spring 1988 could account for the 

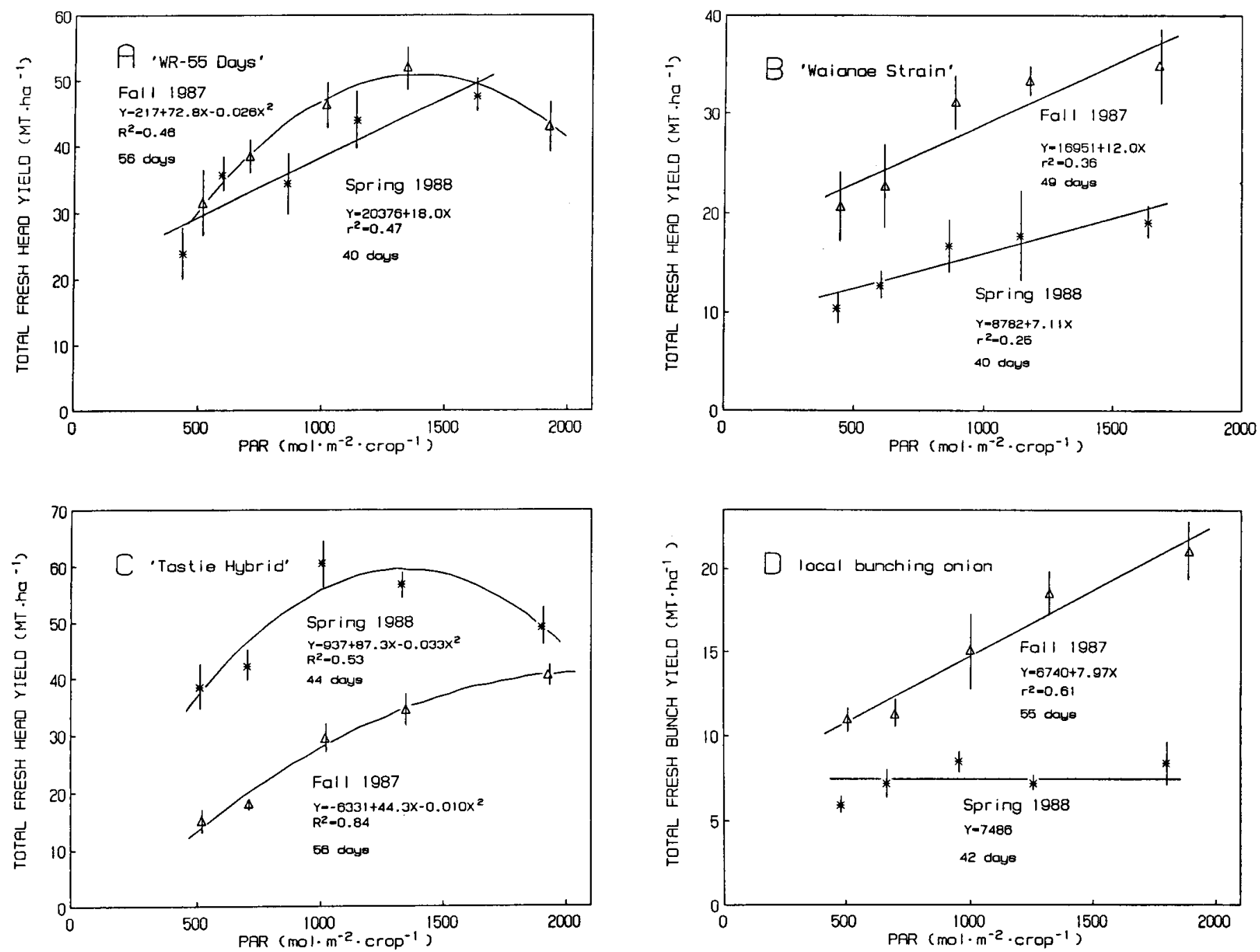

Fig. 5. Total fresh head weight yield of 'WR-55 Days' Chinese cabbage (A), 'Waianae Strain' green mustard cabbage (B), 'Tastie Hybrid' head cabbage (C), and total fresh bunch weight of an unnamed local selection of green bunching onions (D) grown during Fall 1987 and Spring 1988 as a function of accumulated photosynthetically active radiation (PAR) per crop. Days indicated is length of crop cycle. Vertical bars represent the SE.

increased yields obtained under moderate shade with 'Green Mignonette', 'Salinas', and 'Amaral 400' lettuce (Fig. 2A, B, and D) and head cabbage (Fig. 3C) compared to the full-sun plots during Spring 1988. Above 63\% shade, Pn may have become limiting. Evaporation under the $73 \%$ shade canopy was reduced 36\% in Fall 1987 and 41\% in Spring 1988, compared to evaporation in full-sun (data not shown).

Shading reduced maximum air temperatures by $\approx 1 \mathrm{C}$ per $15 \%$ increase in shade level. Minimum air temperatures were not affected by shade (data not shown). Shading also reduced maximum soil temperatures and prevented large diurnal fluctuations (Table 2), as previously reported (Monteith, 1973).

This study was undertaken to determine if artificial shading could enhance yields of leafy vegetable crops grown in Hawaii. These results indicate that shading as a leafy vegetable management practice in Hawaii is ill-advised for cos lettuce, green mustard cabbage, and green bunching onions, but that levels of $30 \%$ to $40 \%$ shade may have potential for improving yields of semihead and head lettuces, and head cabbages under certain conditions. While inconclusive, the data suggest that limited
Table 2. Average minimum and maximum soil temperatures during Spring 1988 and soil water tension during Fall 1987 and Spring 1988 as a function of shading.

\begin{tabular}{cccccc}
\hline \hline \multirow{2}{*}{$\begin{array}{c}\text { Shading } \\
(\%)\end{array}$} & \multicolumn{2}{c}{ Soil temp $\left({ }^{\circ} \mathrm{C}\right)$} & & \multicolumn{2}{c}{ Soil water tension $(-\mathrm{kPa})$} \\
\cline { 2 - 3 } \cline { 5 - 6 } & Minimum & Maximum & & Fall 1987 & Spring 1988 \\
\hline 0 & 24.4 & 36.1 & & 6.7 & 10.9 \\
30 & --- &.-- & & 8.2 & 8.1 \\
47 & 28.7 & 33.3 & & 5.5 & 4.2 \\
63 & --- &.-- & & 7.7 & 2.2 \\
73 & 22.3 & 26.9 & & 5.6 & 4.5 \\
Significance & & & & \\
Linear & $*$ & $*$ & & NS & $*$ \\
Quadratic & $*$ & $*$ & & NS & NS \\
\hline
\end{tabular}

Ns, ${ }^{*}$ Nonsignificant or significant at $P=0.05$, respectively.

soil moisture may predispose crops to respond favorably to shading. Certain crops, such as Chinese cabbage, may have responded positively to shading in Fall 1987 because of the cooler temperatures under shade when the average maximum air temperatures were supraoptimal. 


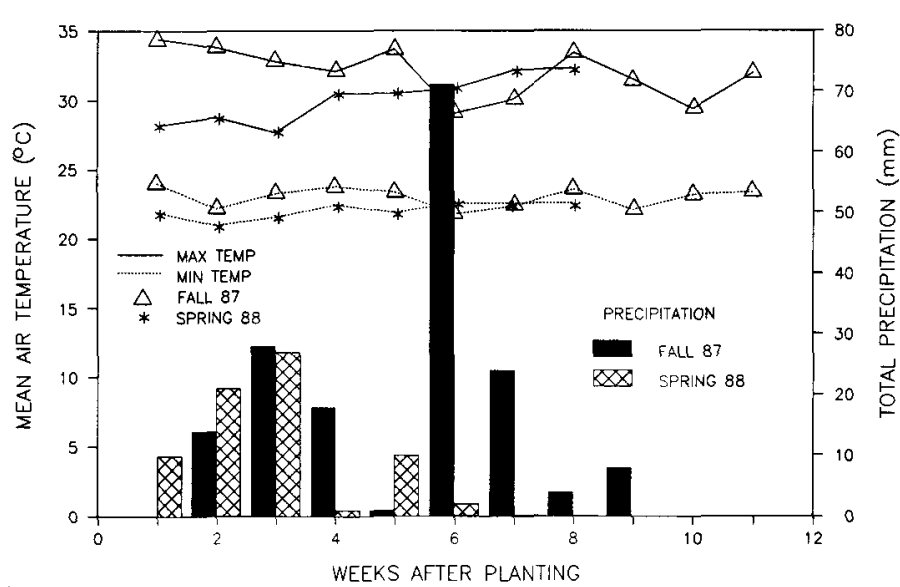

Fig. 6. Mean weekly minimum and maximum air temperatures and total weekly precipitation during Fall 1987 and Spring 1988.

The results of this and previous studies (Wolff and Coltman, 1989) indicate that the greatest potential for improving profitability of crop production by shading in Hawaii exists with 'Green Mignonette' lettuce. This lettuce cultivar is grown intensively in Hawaii (five to six crops per year) on small (0.5to 1.0-ha) farms. Growers of 'Green Mignonette' lettuce, as well as some other leafy vegetables, incur significant costs in Hawaii from attempting to cool their crops with overhead irrigation (S. Fukuda, Oahu Co. Coop. Ext. Serv., personal communication). The $40 \%$ average semihead lettuce yield increases associated with moderate shading in two of three studies [including previous work (Wolff and Coltman, 1989)] suggest that shading may be cost-effective with this crop, not only by increasing yields, but also by reducing irrigation costs. More work needs to be conducted to define the conditions under which positive responses to shading can be expected with 'Green Mignonette' lettuce and also with other lettuce and cabbage cultivars that conceivably could be shaded under commercial conditions, e.g., as components of intercrops.

\section{Literature Cited}

Boardman, N.K. 1977. Comparative photosynthesis of sun and shade plants. Annu. Rev. Plant Physiol. 28:355-377.
Coltman, R.R. 1987. Yields of greenhouse tomatoes managed to maintain specific petiole sap nitrate levels. HortScience 23:148-151.

Ekern, P.C. 1983. Measured evaporation in high rainfall areas, leeward Koolau Ranges, Oahu, Hawaii. Water Resources Res. Ctr., Univ. of Hawaii at Manoa. Tech. Rpt. 156.

Glenn, E.P. 1984. Seasonal effects of radiation and temperature on growth of greenhouse lettuce in a high insolation desert environment. Scientia Hort. 22:9-21.

Hartmann, R., Y. Nakagawa, and R. Sakuoka. 1978a. Lettuce. Hawaii Coop. Ext. Serv., College of Trop. Agr. and Human Resources, Honolulu. Home Garden Veg. Ser. 2.

Hartmann, R., Y. Nakagawa, and R. Sakuoka. 1978b. Mustard cabbage. Hawaii Coop. Ext. Serv., College of Trop. Agr. and Human Resources, Honolulu. Home Garden Veg, Ser. 10.

Heath, O.V.S. 1969. The physiological aspects of photosynthesis. Stanford Univ. Press, Stanford, Calif.

Lorenz, O.A. and K.B. Tyler. 1983. Plant tissue analysis of vegetable crops, p, 24-29. In: H.M. Reisenauer (ed.). Soil and plant tissue testing in California, Div. of Agr, Sci., Univ. of Calif., Berkeley. Bul. 1979.

Mattei, F., L. Sebastiani, and D. Gibbon. 1973. The effect of radiant energy on growth of Lactuca sativa L. J. Hort. Sci. 48:311-313.

Meek, D.W., J.L. Hatfield, T.A. Howell, S.B. Idso, and R.J. Reginato. 1984. A generalized relationship between photosynthetically active radiation and solar radiation. Agron. J. 76:939-945.

Monteith, J.L. 1973. Principles of environmental physics. Elsevier, New York.

Nothmann, J. 1977. Effects of soil temperature on head development of cos lettuce. Scientia Hort. 7:97-105.

Sajjapongse, A. and Y.C. Roan. 1983. Effect of shading and leaf-tying on summer Chinese cabbage. HortScience 18:464-465.

Sale, P.J.M. 1975. Productivity of vegetable crops in a region of high solar input: IV. Field chamber measurements of French beans (Phaseolus vulgaris L.) and cabbages (Brassica oleracea L.). Austral. J. Plant Physiol. 2:461-470.

Takeda, K. and R. Sakuoka. 1979. Onions-bulb and green bunching types. Hawaii Coop. Ext. Serv., College of Trop. Agr. and Human Resources, Honolulu. Home Garden Veg. Ser. 16.

Wallace, G.F. and P. Barrett. 1981. Analytical methods development for inductively coupled plasma spectrometry. Perkin-Elmer, Norwalk, Conn.

Wolff, X.Y. and R.R. Coltman. 1990. Productivity under shade in Hawaii of five crops grown as vegetables in the tropics. J. Amer. Soc. Hort. Sci. 115(1):175-181.

Yamaguchi, M., K.N. Paulson, M.N. Kinsella, and R.A. Bernhard. 1975. Effects of soil temperature on growth and quality of onion bulbs (Allium cepa L.) used for dehydration. J. Amer. Soc. Hort. Sci. 100:415-419. 